\title{
CORRECTION
}

\section{Correction to: Study Protocol for the Effects of Formula Diet with Dapagliflozin on Metabolic Improvement and Body Composition in Type 2 Diabetes Mellitus}

\author{
Yasuhiro Watanabe - Nobuichi Kuribayashi · Daigaku Uchida • \\ Daisuke Suzuki · Mitsutoshi Kato • Daiji Nagayama · Hiroshi Ohashi · \\ Masahiro Ohira $\cdot$ Atsuhito Saiki · Ichiro Tatsuno \\ Published online: February 12, 2020 \\ (C) The Author(s) 2020 \\ Correction to: Diabetes Ther (2019) 10:311-321 \\ https://doi.org/10.1007/s13300-018-0555-5
}

In the original article, the 6 th sentence of the section "FD and calorie intake" is incorrect. The correct sentence is "The protein component of FD consists of whey protein, casein, and soy protein".

There is a correction in the "Inclusion criteria" section, the correct sentence is Estimated glomerular filtration rate $(\mathrm{eGFR}) \geq 45 \mathrm{ml} / \mathrm{min} /$ $1.73 \mathrm{~m}^{2}$.

The original article can be found online at https://doi. org/10.1007/s13300-018-0555-5.

\author{
Y. Watanabe $\cdot$ M. Ohira $\cdot$ A. Saiki $\cdot$ I. Tatsuno $(\bowtie)$ \\ Center of Diabetes, Endocrinology and Metabolism, \\ Toho University Sakura Medical Center, Chiba, \\ Japan \\ e-mail: ichiro.tatsuno@med.toho-u.ac.jp \\ N. Kuribayashi \\ Misaki Naika Clinic, Chiba, Japan \\ D. Uchida \\ Hotaruno Central Naika, Chiba, Japan \\ D. Suzuki \\ Suzuki Diabetes Clinic, Kanagawa, Japan \\ M. Kato \\ Kato Clinic of Internal Medicine, Tokyo, Japan \\ D. Nagayama \\ Nagayama Clinic, Tochigi, Japan \\ H. Ohashi \\ Oyama East Clinic, Tochigi, Japan
}

Open Access. This article is distributed under the terms of the Creative Commons Attribution-NonCommercial 4.0 International License (http://creativecommons.org/licenses/ by-nc/4.0/), which permits any noncommercial use, distribution, and reproduction in any medium, provided you give appropriate credit to the original author(s) and the source, provide a link to the Creative Commons license, and indicate if changes were made. 